\title{
OCCUPATIONAL VIOLENCE AGAINST SECONDARY SCHOOLS' TEACHERS IN ISMAILIA CITY
}

\author{
By \\ Waheed A. and Youssef I.* \\ FROM \\ Departments of Puplic Health, Community Medicine, \\ Occupational and Environmental Medicine, and* Psychiatry, \\ Faculty of Medicine, Suez Canal University
}

\begin{abstract}
Background and Aim of the Work. Violence at work has been identified as a serious problem in many countries all over the world. Violence against teachers has become a silent epidemic in education. Violence can lead to serious adverse health effects. It would be quite impossible for teachers to concentrate in their learning environment if they were suffering from any physical or psychological problems. This work was aimed at determining the prevalence, nature and consequences of physical and non-physical violence against secondary schools' teachers in Ismailia city, and investigating the potential associations between each form of violence and several teacher-related characteristics.
\end{abstract}

Subjects and Methods. This cross sectional study was conducted at secondary schools in Ismailia city, including general, technical, agricultural, industrial, and commercial schools. Eligible teachers were those working for more than one year, and not suffering from any neurological or psychiatric problems. The participant teachers were 1036. A self-administered anonymous questionnaire was used to assess violence against teachers. It covers questions concerning socio-demographic data, job related data and violence incidents; their characteristics, perpetrators, and associated factors. 
Results. About three-fourth of studied teachers were exposed to workplace violence. More than half of them experienced covert violence while $15.8 \%$ experienced overt violence. Actual physical violence was experienced by $7.5 \%$ of the teachers. Near $15 \%$ of respondent teachers were stalked and $4.7 \%$ were sexually harassed. The majority of the stalked and sexually harassed participant teachers were victimized by students, then by other teachers, school administrators, parents or family members, and lastly other school members. The majority of incidents occurred in classrooms and during school time. Only one fourth of the incidents of stalking and sexually harassment were reported to school administrators. Participant teachers reported negative impacts of violence on their own educational career, physical, and emotional status. Logistic regression analysis has revealed that teachers of cultural subjects and teachers with good health status were statistically significantly more exposed to covert and overt assaults. Younger teachers and non-general secondary school teachers were also more prone to covert type of violence. Male teachers and general secondary school teachers were more prone to overt type of violence. The predictors of stalking were longer duration of work in years, ill health, and exposure to overt violence. For sexual harassment, the predictors were exposure to overt violence and nonexposure to stalking.

Conclusion. A significant proportion of secondary school teachers in Ismailia city are exposed to workplace violence, more covert than overt. A smaller proportion is exposed to stalking and sexual harassment. Predictors of violence against teachers included age, gender, experience years, health status, type of school, and subject specialty. There is need for intervention and prevention strategies to provide better quality of life and education for the future of the country.

\section{Introduction}

Violence is a salient public health issue (Hamburg, 1998). Violence at work has dramatically gained momentum in recent years and is now a priority concern in both industrialized and developing countries. Violence at work has been identified as a serious problem in many countries all- over the world (Saarela, 2002). Occupational violence has resulted in physical and psychological damage, and even deaths (Saarela, 2002).

The lack of a clear, concise definition of work-related violence is one of the problems in both tracking and addressing violence as a workplace health and safety 
issue. In workplace settings, the term violence has been applied to a wide spectrum of behaviors ranging from mild abuse to homicide, with little consistency of application (Nolan et al., 1999). Alternatively, according to Duhart (2001), violence at work comprises any physical assaults and threats of assault directed toward persons at work or on duty.

Violence against teachers has become a silent epidemic in education (AEU, 2003). Both teachers and students are facing violence (Mushinski, 1994). Serious assaults against teachers are definitely on the rise and violence against teachers is a workplace hazard of increasing concern (Needham, 2005). However, education authorities seem reluctant to tackle its systemic causes, and while they hesitate, teacher stress levels are increasing and good teachers are leaving (AEU, 2003).

Based on limited information from an advisory committee of teachers, Minnessota University researchers estimated that at least 5 per cent of teachers are assaulted physically each year, and between 20 and 30 per cent are abused nonphysically. Gerberich called nonfatal acts of violence against teachers "seriously underreported" (NIOSH project, 2004-2007). Moreover, between 1996 and 2000, 599,000 violent crimes against teachers at school were re- ported worldwide. The highest incidence was reported in USA where about 28 out of every 1,000 teachers were the victims of violent crime at school, and 3 out of every 1,000 were victims of serious violent crime, i.e. rape, sexual assault, robbery, and aggravated assault (NCES, 2003).

Furthermore, De Voe and coworkers (2002) reported that 9 per cent of all teachers were threatened with injury by a student from their school, and 4 per cent were physically attacked by a student. Also, victims in the teaching profession were more likely than any other workers to report the crimes to a non-law enforcement official (Duhart, 2001).

Most of the violence experienced by teachers tends to be more insidious in nature, consisting of insults, harassment, or intimidating behavior, rather than outwardly threatening or physically violent actions. Incidents involving weapons appear to occur relatively infrequently (Manitoba Teachers Society 1990, 1993; the New Brunswick Teachers' Association, 1994; Nova Scotia Teachers' Union, 1996). The British Colombia survey showed that the range was from $1.0 \%$ for both attempted physical violence with a weapon and actual physical violence with a weapon to $29.5 \%$ for personal insults or name calling (Lyon and Douglas, 1999). Assaults were 
predominately physical, occurring during classroom disputes and while restraining students (Levin et al., 2006).

The most frequent perpetrators of violence against teachers were students, followed by parents/ guardians, youths external to the school, and other teachers, support staff, or administrative officers (The New Brunswick Teachers' Association, 1994; MacDonald et al., 1996; Lyon and Douglas, 1999).

Violence against teachers occurs as a result of a combination of multiple factors. Parental influences, school staff and police involvement, peer pressure, student influences such as drug and alcohol abuse and a preoccupation with weapons, and the mass media have all been identified as possible factors associated with violence against teachers. In addition, individual student characteristics such as gender, socioeconomic status, and a history of prior violence may play a role. However, none of these factors can be identified or singled out as the reason for violence (Ruff et al., 2004). Meanwhile, Johnson and Fisher (2003) identified lack of knowledge, lack of support, and inadequate safety measures as probable causes of school violence. Moreover, lack of parental supervision at home and lack of family involvement in school were considered major factors con- tributing to school violence affecting at least two-thirds of the teachers and 83 per cent or more of the law officers (Mushinski, 1994).

The media also play a very important role in the spread of school violence. The media typically glorifies violence in movies and television shows. In a society that is inundated with media images of violence, it is believed that the cumulative effect, especially for people who are a little unstable, can be a contributing factor to violent behavior (Glasgow, 2003). The problem is not the direct correlation between a student seeing an image on the television or the movies and replicating it; it is the constant exposure to violence that tends to lead the youth to believe that violence is a normal, not deviant behavior (Vossekuil, 2002).

Some teachers are at greater risk for victimization. Male teachers are more than twice as likely to be victims of violent crime, and teachers at middle/junior high schools are at greater risk than those in elementary or senior high schools. Violence against teachers is also higher at urban schools (Reiss et al., 1993) and semirural school district (Johnson and Fisher, 2003). Moreover, the level of violence reported by teachers and the proportions who reported that weapons were regularly 
brought to school increased as the perceived quality of the education provided in the school decreased (Mushinski, 1994).

Violence can lead to serious adverse health effects (Kimerling and Calhoun, 1994; Norris and Kaniasty, 1994; BoneyMcCoy and Finkelhor, 1995; Acierno et al., 1999). Because the direct physical consequences of violence are often visually apparent, their potential impact on a victim's physical health seems to be relatively well understood. Much less understood and appreciated, however, is the "hidden" effect of violence in terms of the victim's psychological well-being. Of particular concern in this regard are chronic forms of violence such as intimidation and harassment, which do not result in immediate physical signs of trauma and therefore are more likely to be minimized or downplayed (Lyon and Douglas, 1999). If an attack does occur at school, those involved are more likely to suffer from posttraumatic stress syndrome. Some symptoms of this disorder are re-experiencing the old trauma, depression, outbursts of anger, irritability, inability to sleep, and lack of concentration (Schonfeld, 1995; Weinhold, 2003).

It would be quite impossible for teachers to concentrate in their learning environment if they were suffering from any of the above listed problems. Some may never be able to completely go back to how their life was before the attack (Phillip, 1999). Therefore, school violence needs to be taken seriously because it creates an environment that is unhealthy for learners as well as for teachers. There is a great deal of anecdotal evidence available from teachers, and a plethora of stories and articles in the media, particularly high profile stories of physical assaults against teachers from students. Despite a wealth of anecdotal evidence, there are currently very little research data available on the prevalence or impact of various forms of physical and emotional violence directed against staff in schools violence (student-to-student and parent-to-teacher), which are perceived to be more serious problem (Lyon and Douglas, 1999).

There are still very little Egyptian research studies pertaining to the consequences of violence against teachers and its adverse health effects. Some Egyptian and Arabian educational studies were concerned with educational problems, and by the way tackled the relation between teachers and students only (Mostaffa, 1993; Hassan, 1997). Meanwhile, Egyptian social studies were only concerned with violence among students and addressed the problem of violence against 
teachers as a secondary issue (Al-Amir, 1993; Hanna, 1998). This provides reason to assess the prevalence, nature, and the health effects of violence against teachers in secondary schools in Ismailia city.

\section{Aim of the Work}

This work was aimed at determining the prevalence, nature and consequences of physical and non-physical violence against secondary schools' teachers in Ismailia city, and investigating the potential associations between each form of violence and several teacher-related characteristics.

\section{Subjects and Methods}

A cross sectional study was conducted in secondary schools in Ismailia city, including general, technical, agricultural, industrial, and commercial secondary schools. Teachers eligible for the study were those working for more than one year, and not suffering from any neurological or psychiatric problems. All eligible working teachers at the study time have participated in the study. Their total number was 1036 teachers out of a total of 3701 secondary school teachers in Ismailia Governorate. The majority of participants were female $(\mathrm{n}=564 ; 54.4 \%)$, with mean age (SD) of $38.83 \pm 7.6$ years ranging from 21 to 58 years old. Most respondents pos- sessed a bachelor's degree as their highest level of education ( $\mathrm{n}=928 ; 89.6 \%$ ). Teachers had, on average, approximately $14.4 \pm 7.1$ years of teaching experience, and $6.5 \pm 4.7$ years teaching at their present school. Most respondents had permanent contracts $(n=945 ; 91.2 \%)$. Slightly more than half $(50.7 \%)$ were in general secondary schools, while commercial, technical, and agricultural schools teachers constituted respectively $18.3 \%, 21.3 \%$, and $9.7 \%$ of the sample.

A self-administered anonymous questionnaire was used to assess violence against teachers. It was designed based on the British Colombia Teachers Federation Survey (Lyon and Douglas, 1999). It is a modified version to Singer exposure to violence scale. It was translated into Arabic by two independent persons after relating some questions to Arabian background.

\section{The questionnaire consisted of two parts:}

Part I: included queries about teacher's socio-demographic data as age, gender, and educational level, in addition to job-related data and school characteristics as subject area specialty, years of experience, grades taught, type of school, number of students, number of staff at school, and average class density. It also included questions about the health status of the participant teacher. 
Part II: covered details about violence at school. It included queries about the violence incidents, and forms of violence with a focus upon stalking and sexual harassment. It also asked about the occurrence and specifics of relevant physical and non-physical work-related violence events during the previous 12 months such as the site (e.g., classroom; other inside location; outside; etc.), context (e.g., regular classroom activities; classroom management; extra-curricular activity; etc.), time of day and lighting conditions, perpetrator (e.g., student in class; parent/guardian; other staff teachers), and perpetrator characteristics (e.g., age; gender; behavioral problems; past violence). Teacher was also asked about the action taken as reporting to specialized authorities, and specific actions against perpetrator. Then, the impact of violence was assessed, where participant were asked about personal experience of specified symptoms and feelings relating to career, physical, and emotional well-being.

A pilot study was conducted on $20 \mathrm{sec}-$ ondary school teachers to test the clarity and feasibility of the tool items. A finalized version of the questionnaire was then prepared accordingly.

\section{Working Definitions}

Definitions of violence utilized in this study were developed by Lyon and Douglas (1999), and di Martino (2002).

Violence is defined as any threatened, attempted, or actual harm to a person or persons. Behavior that would be fearinducing to the average person also falls within the parameters of this definition.

Covert violence is defined as tapped insidious, often continuing, behaviors and experiences apparently capable of creating hostile work environments and apt to increase stress associated with the workplace.

Stalking is defined as abnormal and persistent interest in a specific individual, accompanied by repeated acts of a threatening or harassing nature toward that individual.

Sexual harassment is described as circumstances in which sexual demands, remarks, gestures, or behaviors make the work environment intolerable, or situations in which employment is made contingent upon compliance with sexual demands, remarks, gestures, or behaviors.

The study was conducted after taking permissions from the Ministry of Education in Cairo, then the Director of the Educational Affairs, and lastly from schools' headmasters. Ethical considerations and human rights were taken into account in 
carrying out the study. Complete confidentiality of any obtained information was secured.

\section{Statistical analysis}

Statistical analysis was done using Statistical Package for Social Science (SPSS) version 13.0. Presentation of data was done in the form of numerical and tabular forms as appropriate. Logistic regression analysis was done to assess the influences of demographic, occupational factors, school characteristic and the health status of the participant teachers on the occurrence of violence and its forms. For all tests, statistical significance level was considered at $\mathrm{p}$ value $<0.05$.

\section{Results}

\section{Prevalence and types of violence}

The prevalence of each type of violence is shown in Table 1. More than half of the reported violence was in the form of activities intended to intimidate (52.2\%). Personal insults and name-calling was the most frequent type (26.8\%), while actual physical violence with a weapon was the least frequent $(6.3 \%)$, although it was the most dangerous one. The table also shows that covert violence, which represents nonphysical types of violence that may be insidious or chronic, was much higher (54.7\%), compared to overt violence, which refers to physical violence whether attempted, threatened, or actual, excluding that against family members $(15.8 \%)$. Actual physical violence describes violence in which physical contact was actually made, and accounted for $7.5 \%$ of violence types. Overall, total violence prevalence was as high as $74.7 \%$.

\section{Stalking and Sexual Harassment}

Table 2 describes two specific types of violence, namely stalking and sexual harassment. As the table indicates, $14.5 \%$ and $4.3 \%$ of the participant teachers have reported being exposed to stalking behaviors and sexual harassment, respectively. Two thirds of the perpetrators of stalking behaviors were males $(66.7 \%)$, and near half of them were students $(44.0 \%)$. The most prevalent stalking behavior was communicating $(52.0 \%)$, while vandalism was reported in $8.0 \%$ of the cases. The table also illustrates that perpetrators of sexual harassment were mostly males $(64.4 \%)$, either students $(37.8 \%)$ or teachers $(31.1 \%)$. It was mostly in the form of offensive remarks $(37.8 \%)$, but $8.9 \%$ have reported unwanted touching.

\section{Situational Characteristics}

The situational characteristics of the stalking and sexual harassment violence incidents revealed that slightly higher than 
one fifth took place in the classroom, while school hallways were the next (15.4\%). Almost half of the incidents occurred during school time (46.2\%), and in daylight $(59.0 \%)$, as shown in table 3 . However, still a high percentage did not mention the details of the incident. As regards the consequence of such violence, the same table indicates that near one fifth of the incidents resulted in physical injuries $(19.5 \%)$, which were severe in three cases $(7.9 \%)$. Other consequences involved absenteeism from work $(24.6 \%)$, which was mainly due to stress $(72.9 \%)$.

\section{Reporting of violent incidents}

Regarding reporting of the violent stalking and sexual harassment incidents, table 4 demonstrates that only $25.6 \%$ of the incidents were reported. This was mostly to school administrators (46.0\%), although $18.0 \%$ were reported to police. Violent incidents were reported less frequently to parents $(8.0 \%)$. As for the reason for not reporting, the most frequently mentioned one was solving the problem informally $(19.3 \%)$, or because no action would be taken if the incident was reported (18.9\%). However, still about one fourth of non-reporters gave no reason for not reporting (32.4\%). Concerning the action taken, the table indicates that in most of the cases, nothing was done (73.8\%).
The most frequent type of action taken was just to alternate student placement $(8.7 \%)$, or suspension $(7.7 \%)$. In only two cases $(1.0 \%)$, the action was student expulsion.

\section{Impact of violence}

Table 5 illustrates participant teachers' reported impact of violence on their own career, physical, and emotional status. Regarding career, such incidents affected the career performance of more than half of the respondents (55.9\%). This was mainly in the form of poorer job performance $(27.5 \%)$, and decreased job satisfaction $(19.3 \%)$. Nine teachers $(8.3 \%)$ have reported having changed school as a result of violence incidents. Violence was also responsible for physical symptoms manifested by more than one third of teachers (37.9\%). The most frequently reported physical symptoms were sleep disturbance, headache, and gastro-intestinal upsets, $14.9 \%, 8.1 \%$, and $5.4 \%$, respectively. The table also shows that more than half of teachers were complaining from more than one single symptom (55.4\%).

Regarding emotional impact, the same table shows that more than half of the teachers had psychological symptoms (51.8\%). The most common symptoms were frustration (20.8\%), anger (12.9\%), and sadness (11.9\%). Complaining from 
more than one symptom was reported by about one forth of respondents (25.7\%).

Risk factors associated with violence against secondary school teachers

Logistic regression analysis was carried out to determine personal and school characteristics affecting the occurrence of violence against teachers. Table 6 displays the best fitting models for covert and overt types of violence. Teachers of cultural subjects and teachers not suffering from health problems turned to be statistically significant more exposed to covert and overt assaults. In addition, as shown in the table, younger teachers and non-general secondary school teachers were also more prone to covert type of violence. Meanwhile, male teachers and general secondary school teachers were more prone to overt type of violence.

Table 7 also depicts the predictors of stalking and sexual harassment. The predictors of stalking were longer duration of work in years, ill health status of teachers and exposure to overt violence. As for sexual harassment, the predictors were exposure to overt violence and un-exposure to stalking.

Table 1. Violence against secondary school teachers in Ismailia city $(n=1036)$

\begin{tabular}{|l|c|c|}
\hline \multicolumn{1}{|c|}{ Types of violence } & Frequency & $\%$ \\
\hline Covert violence: & 541 & 52.2 \\
Chronic activities tolerable on own but in total intended to intimidate & 278 & 26.8 \\
Personal insults or name-calling & 214 & 20.7 \\
Rude or obscene gestures intended to offend/insult/intimidate you & 200 & 19.3 \\
Behavior or conduct intended to make you fearful or intimidated & 154 & 14.9 \\
Remarks/statements made to harm your reputation or relationships & 567 & 54.7 \\
Total covert: & & \\
Overt violence: & 101 & 9.7 \\
Threatened physical violence without a weapon & 99 & 9.6 \\
Threatened/attempted/actual violence against a family member & 92 & 8.9 \\
Personal property damage & 79 & 7.6 \\
Attempted physical violence without a weapon & 73 & 7.0 \\
Threatened physical violence with a weapon & 69 & 6.7 \\
Actual physical violence without a weapon & 68 & 6.6 \\
Attempted physical violence with a weapon & 65 & 6.3 \\
Actual physical violence with a weapon & 164 & 15.8 \\
Total overt & 78 & 7.5 \\
Actual physical violence & 774 & 74.4 \\
Total (all violence) & & \\
\hline
\end{tabular}


Table 2. Stalking and sexual harassment against participant teachers $(n=1036)$

\begin{tabular}{|c|c|c|}
\hline Nature of harassment & Frequency & Percent \\
\hline Stalking & 150 & 14.5 \\
\hline \multicolumn{3}{|l|}{ Perpetrator gender: } \\
\hline Male & 100 & 66.7 \\
\hline Female & 36 & 24.0 \\
\hline Not mentioned & 14 & 9.3 \\
\hline \multicolumn{3}{|l|}{ Relation to teacher: } \\
\hline Student & 66 & 44.0 \\
\hline Teacher & 29 & 19.3 \\
\hline Administrator & 20 & 13.3 \\
\hline Parent/family member & 19 & 12.7 \\
\hline School member & 7 & 4.7 \\
\hline Not identified & 9 & 6.0 \\
\hline \multicolumn{3}{|l|}{ Nature of stalking: } \\
\hline Communicating & 78 & 52.0 \\
\hline Watching & 17 & 11.3 \\
\hline Unwanted gifts & 16 & 10.7 \\
\hline Vandalism & 12 & 8.0 \\
\hline Following & 8 & 5.3 \\
\hline Other & 13 & 8.7 \\
\hline Not identified & 6 & 4.0 \\
\hline Sexual Harassment & 45 & 4.3 \\
\hline \multicolumn{3}{|l|}{ Perpetrator gender: } \\
\hline Male & 29 & 64.4 \\
\hline Female & 12 & 26.7 \\
\hline Not mentioned & 4 & 8.9 \\
\hline \multicolumn{3}{|l|}{ Relation to teacher: } \\
\hline Student & 17 & 37.8 \\
\hline Teacher & 14 & 31.1 \\
\hline Parent/family member & 5 & 11.1 \\
\hline School member & 5 & 11.1 \\
\hline Administrator & 4 & 8.9 \\
\hline \multicolumn{3}{|l|}{ Nature of sexual harassment: } \\
\hline Crude and offensive remarks & 17 & 37.8 \\
\hline Trial to establish sexual relationship & 9 & 20.0 \\
\hline Staring, leering, ogling & 9 & 20.0 \\
\hline Unwanted touching & 4 & 8.9 \\
\hline Subtle bribery for sexual favors & 2 & 4.4 \\
\hline Other & 2 & 4.4 \\
\hline Not mentioned & 2 & 4.4 \\
\hline
\end{tabular}


Table 3. Situational characteristics of stalking and sexual harassment violence experienced by participating teachers $(n=195)$

\begin{tabular}{|l|c|c|}
\hline Situational characteristics: & Frequency & Percent \\
\hline Location: & & \\
Classroom & 32 & 21.5 \\
Hallway & 23 & 15.4 \\
Non-school location & 18 & 11.8 \\
Courtyard & 5 & 9.2 \\
Teachers' room & 19 & 2.6 \\
Other & 58 & 9.7 \\
Not mentioned & & 29.7 \\
Timing: & 13 & \\
Before school & 90 & 6.7 \\
During school & 30 & 46.2 \\
After school & 62 & 15.4 \\
Not mentioned & & 31.8 \\
Time of day: & 115 & \\
Daylight & 14 & 59.0 \\
Afternoon & 66 & 7.2 \\
Not & & 33.8 \\
Consequences: & 38 & \\
Physical injuries: & 28 & 19.5 \\
Minor injury & 7 & 73.7 \\
Moderate injury & 3 & 18.4 \\
Severe injury & 48 & 2.9 \\
Time missed from work: & 35 & 72.9 \\
Due to stress & 7 & 14.6 \\
Due to physical injuries & 6 & 12.5 \\
Other reasons & & \\
\hline
\end{tabular}


Table 4. Characteristics of violent incident reporting and action taken

\begin{tabular}{|l|c|c|}
\hline & Frequency & $\%$ \\
\hline Characteristics of reporting: & 50 & 25.6 \\
Incident reported & & \\
$\quad$ Agency notified (n=50): & 23 & 46.0 \\
$\quad$ School administrator & 9 & 18.0 \\
$\quad$ Police & 4 & 8.0 \\
$\quad$ Parent & 14 & 28.0 \\
$\quad$ Other & & \\
Reason for not reporting (n=145): & 28 & 19.3 \\
Informal resolution reached & 27 & 18.6 \\
$\quad$ No action would be taken & 20 & 13.8 \\
It happens all the time & 14 & 9.7 \\
To avoid causing trouble to perpetrator & 9 & 6.2 \\
Other & 47 & 32.4 \\
No reason & & \\
Action taken: & 144 & 73.8 \\
Nothing & 17 & 8.7 \\
Alternate student placement & 15 & 7.7 \\
Student suspension & 5 & 2.6 \\
Change of teaching assignment & 2 & 1.0 \\
Student expulsion & 12 & 6.2 \\
Other & & \\
\hline
\end{tabular}


Table 5. Impact of violence on participant teachers

\begin{tabular}{|c|c|c|}
\hline & Frequency & Percent \\
\hline Experienced career impact & 109 & 55.9 \\
\hline \multicolumn{3}{|l|}{ Types $(n=109)$ : } \\
\hline Poor performance & 30 & 27.5 \\
\hline Decreased job satisfaction & 21 & 19.3 \\
\hline Absenteeism & 13 & 11.9 \\
\hline Changed assignment within school & 10 & 9.2 \\
\hline Changed school & 9 & 8.3 \\
\hline Other & 7 & 6.4 \\
\hline More than one type & 19 & 17.4 \\
\hline Had physical symptoms & 74 & 37.9 \\
\hline \multicolumn{3}{|l|}{ Types $(n=74)$ : } \\
\hline Sleep disturbances & 11 & 14.9 \\
\hline Headache & 6 & 8.1 \\
\hline Gastrointestinal upsets & 4 & 5.4 \\
\hline Backache & 3 & 4.1 \\
\hline Dizziness and tremors & 3 & 4.1 \\
\hline Weight change & 2 & 2.7 \\
\hline Hyper-alertness & 2 & 2.7 \\
\hline Other & 2 & 2.7 \\
\hline More than one symptom & 41 & 55.4 \\
\hline Had psychological symptoms & 101 & 51.8 \\
\hline \multicolumn{3}{|l|}{ Types $(n=101)$ : } \\
\hline Frustration & 21 & 20.8 \\
\hline Anger & 13 & 12.9 \\
\hline Sadness & 12 & 11.9 \\
\hline Depression & 8 & 7.9 \\
\hline Irritability & 8 & 7.9 \\
\hline Increased stress & 7 & 6.9 \\
\hline Low self-esteem & 4 & 4.0 \\
\hline Anxiety & 2 & 2.0 \\
\hline More than one symptom & 26 & 25.7 \\
\hline
\end{tabular}


Table 6. Logistic regression models of covert and overt types of violence and their independent predictors*

\begin{tabular}{|l|c|c|c|c|c|}
\hline Type of violence & $\begin{array}{c}\text { Beta } \\
\text { coefficient }\end{array}$ & $\begin{array}{c}\text { Standard } \\
\text { error (B) }\end{array}$ & Wald & p-value & Exp (B) \\
\hline Covert "non- physical" violence: & & & & & \\
Age (reference: younger than 35 years) & -0.375 & 0.016 & 5.516 & 0.019 & 0.964 \\
Teaching subject (reference: cultural) & -0.326 & 0.133 & 6.027 & 0.014 & 0.722 \\
Type of secondary school (reference: general) & 0.153 & 0.072 & 4.551 & 0.033 & 1.166 \\
Medical status (reference: ill health) & 0.028 & 0.010 & 8.526 & 0.004 & 1.028 \\
Constant & 1.546 & 0.766 & 4.074 & 0.044 & 1.692 \\
\hline Overt " physical" violence & & & & & \\
Gender (reference: male) & -0.576 & 0.178 & 10.428 & 0.001 & 0.562 \\
Teaching subject (reference: cultural) & -0.454 & 0.188 & 5.826 & 0.016 & 0.635 \\
Type of secondary school (reference: general) & -0.027 & 0.100 & 5.944 & 0.015 & 0.784 \\
Medical status (reference: ill health) & 0.027 & 0.010 & 7.559 & 0.006 & 1.027 \\
Constant & 2.664 & 1.013 & 6.917 & 0.009 & 14.350 \\
\hline
\end{tabular}

Independent predictors tested: gender, age, educational level, work duration in years, type of contract, teaching subject, number of classes per week, type of secondary school and medical status.

Table 7. Logistic regression models of stalking and sexual harassment and their independent predictors

\begin{tabular}{|l|c|c|c|c|c|}
\hline & $\begin{array}{c}\text { Beta } \\
\text { coefficient }\end{array}$ & $\begin{array}{c}\text { Standard } \\
\text { error (B) }\end{array}$ & Wald & p-value & Exp (B) \\
\hline Stalking & & & & & \\
Work duration (reference: short duration $<10$ years) & 0.056 & 0.026 & 4.733 & 0.030 & 1.057 \\
Medical status (reference: ill health) & -0.038 & 0.011 & 12.182 & $<0.001$ & 0.962 \\
Exposure to overt violence (reference: exposed) & -0.956 & 0.081 & 140.639 & $<0.001$ & 0.385 \\
Constant & 2.425 & 1.176 & 4.248 & 0.039 & 11.297 \\
Sexual harassment & & & & & \\
\hline Exposure to overt violence (reference: exposed) & -0.284 & 0.101 & 7.905 & 0.005 & 0.752 \\
Exposure to stalking (reference: exposed) & 3.701 & 0.523 & 50.145 & $<0.001$ & 40.501 \\
Constant & -5.758 & 2.644 & 4.741 & 0.029 & 0.003 \\
\hline
\end{tabular}

Independent predictors tested: gender, age, educational level, work duration in years, type of contract, teaching subject, number of classes per week, type of secondary school, medical status, exposure to covert ,overt violence and exposure to stalking. 


\section{Discussion}

Schools should be safe and secure places for all students, teachers, and staff members. Without a safe learning environment, teachers may have difficulty teaching and students may have difficulty learning. The current study showed that most secondary school teachers in Ismailia city were exposed to some type of workplace violence. More than half of the participant teachers experienced covert violence while about fifteen percent experienced overt violence. The actual physical violence was experienced by seven and half percent of the participant teachers. Near fifteen percent of teachers of the current study had been stalked and near five percent had been sexually harassed. The Saskatchewan Teachers' Federation survey (1994) results are in agreement with the current findings regarding elements of covert violence and overt one despite the cultural differences and differences in reporting of physical incidents. The most common types of violence reported in the Canadian survey were personal insults or name calling, remarks or statements intended to harm teachers' reputation or relationships, rude or obscene gestures intended to offend, insult, or intimidate, directly threatening behavior, and lastly actual or attempted physical violence. However, chronic activities tolerable on their own but in total designed to trouble or intimidate the teacher accounted for only $15 \%$ in the Canadian study, compared to more than $50 \%$ in our study. This might reflect cultural differences, as this type of violence reflects less overtly aggressive behavior.

In congruence with the current results, the survey of Post Primary Teachers Association (PPTA), New Zealand showed that $85 \%$ of teachers reported less frequent but more significant bullying incidents within a school year (PPTA, 2004). Also, close to the current results, $45 \%$ of the surveyed Canadian teachers of the Manitoba Teachers Society survey $(1990,1993)$ were subjected to verbal abuse, $8 \%$ were threatened with physical injury, $10 \%$ were physically attacked, and slightly more than $10 \%$ suffered property damage.

The New Brunswick Teachers' Association (1994) survey of the entire Englishspeaking membership regarding their experiences with violence between September 1991 and April 1993 gave results that are slightly lower than the present study. Thus, nearly $40 \%$ of the respondents had been victims of some type of work-related violence, compared to more than $70 \%$ in the present study. The five most common forms of abuse reported by respondents during the study period were verbal abuse 
or obscene gestures (34\%), harassment due to their occupation (14\%), property damage $(12 \%)$, threats of physical injury $(12 \%)$, and physical attacks (9\%). However, this last type of actual physical attacks was slightly lower than that revealed in the present study. Moreover, property damage was lower in the present study.

The British Colombia Teachers' Federation survey (1999) showed that $43.3 \%$ of the participants experienced covert forms of violence, $9.8 \%$ of them reported overt violence and approximately $5 \%$ of respondents reported actual physical violence in 1997/98. These findings are more close to New Brunswick Teachers' Association (1994) survey than to the current results, which again confirms the effect of cultural differences. Moreover, teachers in the British Colombia Teachers' Federation survey reported less stalking (5\%) and more sexual harassment $(12 \%)$. This is quite the reverse of the current findings where stalking was much higher than sexual harassment. Although there is no difference regarding violence definitions between this survey and the current work, the differences may be due to cultural differences, and the time period of interest. The higher levels of sexual harassment might be due to different workplace setting or using more liberal definitions of sexual harassment (Lyon and Douglas, 1999).
More recently, in a NIOSH project based on limited information from an advisory committee of teachers, Minnesota University researchers estimated at least 5 per cent of teachers are assaulted physically each year and between 20 and 30 per cent are abused non-physically. These figures indicate much lower experiences with violence, compared to previous studies, and also compared to the present study. However, this might reflect underreporting as Gerberich called nonfatal acts of violence against teachers "seriously underreported" (NIOSH project, 2004-2007). This is in line with the present study findings, where only a small minority of violent incidents was reported, either to school administrators, or to police. In congruence with this finding, Duhart (2001) has mentioned that in the teaching category, only $28.1 \%$ of violent crimes were reported to police and $52.1 \%$ dealt with in another way. Underreporting in the current work was mostly due to informal resolution of the incident, or persuasion of teachers that nothing would be done, which reflects passive behavior of victims. These findings are in line with those of British Colombia Teachers' Federation survey, which mentioned that the lower reporting levels reflect the reluctance of victims to make complaints about colleagues when 
they may have to continue working alongside these individuals after the complaint is lodged, or might be due to the absence of physical injuries (Lyon and Douglas, 1999). Meanwhile, Day et al. (1995) have claimed that the greater the sense of teachers' personal self-efficacy to manage behavior problems and the higher their perceived support from the school and the school board, the lower the level of perceived violence. This could also explain why greater teaching experience and school policies are associated with lower rates of reported violence.

The majority of the participant teachers in the present study were victimized by students, then by other teachers, school administrators, parents or family members, and lastly other school members. This in agreement with many previous studies (Manitoba Teachers Society, 1990 and 1993; New Brunswick Teachers' Association, 1994; MacDonald, 1996; Nova Scotia Teachers' Union, 1996; Lyon and Douglas, 1999; NCES, 2003; Scottish Executive National Statistics, 2003; PPTA, 2004). All these studies, in accordance with the present one, have pointed that all people around teachers were sharing as perpetrators, but the most common perpetrators were students. This supports that the problem is not the direct correlation between a student seeing an image on television or in the movies and replicating it. It is the constant exposure to violence that tends to lead the youth to believe that violence is a normal, not a deviant behavior (Vossekuil, 2002). Violence at home and in the media seems to foster violent acting-out behavior (Lyon and Douglas, 1999).

The majority of the perpetrators of stalking and sexual harassment in the current work were males. This is quite plausible as this behavior is more likely among males, particularly in conservative communities as ours. The finding is in congruence with Benefield (2004) who has claimed that male pupils were more aggressors, compared to females.

In terms of situational characteristics, the current study results have shown that most violent incidents occurred within school premises, especially classrooms and school hallways. As might be expected, the majority of violence occurred during school hours. This is in accordance with British Colombia Teachers' Federation Survey and Post Primary Teachers Association Survey (Lyon and Douglas, 1999 and PPTA, 2004). Physical and verbal aggressions occur more inside school limits. Moreover, Levin et al. (2006), in their retrospective study, showed that assaults were predominately occurring dur- 
ing classroom disputes and while restraining students. As a consequence, even though the academic level of students might be good, the climate in schools is worse and shows a stronger opposition to adults, especially to teachers (Connect Initiative, 2002).

Concerning the impact of violence, current study respondent teachers have reported that exposure to workplace violence had negative effects on their own career, job satisfaction, and job performance, in addition to the physical and psychological effects. The relationship of violence to these different outcomes reported in the current work parallels the larger empirical literature on the effects of violent victimization (Norris and Kaniasty, 1994; Schonfeld, 1995; Acierno et al., 1999; Lyon and Douglas, 1999). Experiences of violence cause fear, and feelings of fear, in turn, cause increased levels of emotional and physical symptomatology. Violence and fear have an adverse impact on morale, job satisfaction, and perceptions of violence (Lyon and Douglas 1999). These effects include many, if not most, of the symptoms experienced in the current study, as well as potentially more serious effects such as major depression or posttraumatic stress disorder (Schonfeld, 1995; Lyon and Douglas, 1999).
Furthermore, Fisher and Kettl (2003) have demonstrated that fifty-six percent of teachers believed that violence or the threat of violence had a direct impact on the quality of education they are able to provide. Also in the same vein, Mushinski (1994) has claimed that the level of violence reported by teachers and the proportions who reported that weapons were regularly brought to school increased as the perceived quality of the education provided in the school decreased.

In line with the current findings where the majority of physical injuries were minor, the British Colombia Teachers' Federation survey (1999) showed that most teachers have not experienced serious forms of violence. It is also relieving to find that most teachers have not been injured physically by violence at the workplace. However, it is disconcerting that teachers experience any such violence, and it is more disconcerting that most teachers have experienced some form of violence during the course of their careers. The results of that Canadian survey suggested that the experience of violence, whether overt or covert, was related to, inter alia, a variety of negative repercussions, such as increased fear at school, decreased perceptions of morale and teaching effectiveness, career impact symptoms (e.g., decreased 
job satisfaction), physical symptoms (e.g., sleep disturbances, headaches, fatigue), and emotional symptoms (e.g., frustration, anxiety, irritability, anger, stress), which coincides with the current results (Lyon and Douglas, 1999).

Importantly, the impact of violence should not be discounted simply because it does not involve overt forms of violence or actual physical contact. Teachers were most likely to miss work when the perpetrator of aggression was another staff member. Yet, every one of these incidents was limited to covert forms of violence. There are two probable explanations for this finding. First, because the physical injuries from the violence reported in the current work tended to be minor, they generally did not require time off from work for recovery. Second, even when physical injuries did not occur, violence still had a serious negative impact on the psychological and emotional functioning of some victims. Apparently this psychological trauma led victims to take time away from work more often than did physical injuries. This is in accordance with that of British Colombia Teachers' Federation Survey (Lyon and Douglas, 1999).

The current work showed that younger teachers were more exposed to covert forms of workplace violence, while male teachers were more exposed to overt forms. Both overt and covert forms increased among teachers with good health, and those who taught cultural subjects. It is interesting to find that non-general secondary school teachers were more exposed to covert form while general secondary school teachers were more exposed to overt form. The results of the New Zealand survey regarding bullying against secondary school teachers, which including overt violence, found that there were two spikes of increasing bullying against youngest as well as elder teachers. This was explained by the fact that teachers within these groups are more likely to be themselves management staff, and this finding is consistent with those of management staff reports of bullying from management staff (Benefield, 2004).

According to the present study results, physical violence was higher against male teachers. In line to this finding, De Voe et al (2002) and NCES (2003) found that male teachers were more likely to be victims of violent crime. Moreover, the British Colombia Teachers' Federation survey (1999) showed that young teachers and male teachers (except for sexual harassment and stalking) were more exposed to violence (Lyon and Douglas, 1999). Conversely, the New Zealand findings showed 
that more women teachers reported bullying from all sources than men (Benefield, 2004). The differences might be explained by different feminine cultures, where in our community women's conception of physical violence and the level of tolerance might be different from western communities.

Stalking against present study teachers was predicted by longer duration of employment as a teacher, ill healthy status, and exposure to overt violence. In contrast, the British Colombia teachers with fewer years of teaching experience were found to have experienced more violence (Lyon and Douglas, 1999). Exposure to overt violence and un-exposure to stalking were predictors of the occurrence of sexual violence against the present study teachers. Richman et al. (1999) highlighted the public health significance of both sexual harassment and generalized workplace abuse, which are significantly associated with a diverse range of negative mental health outcomes. It is uncertain to what extent harassment and abuse predict deleterious mental health outcomes or to what extent individuals with mental health problems are differentially prone to evoke problematic workplace interactions. Alternatively, individuals with mental health problems may differentially perceive interactions as harassing or abusive.

\section{Conclusion and Recommendations}

A significant proportion of secondary school teachers in Ismailia city are exposed to workplace violence, more covert than overt. A smaller proportion is exposed to stalking and sexual harassment. Predictors of violence against teachers included age, gender, experience years, health status, type of school, subject specialty, and exposure to other forms of violence.

The findings suggest that medical, educational and social researchers should play a proactive role in translating research-supported preventive strategies to effective replications, and make research available in formats that are available and comprehensible to lay public. The solutions will take time, resources, and commitment to address the issue of violence in schools, and must encompass the community as a whole. School nurses should have a role to develop interventions for students, teachers, and families that stress knowledge building about impulse control, anger management, appropriate parenting, and early intervention for at-risk children. School-based violence prevention and intervention programs are urgently needed. Education officials and school operators should have to make joint efforts to restore trust between teachers, students and parents, as well as provide better quality education. 


\section{REFERENCES}

1. Acierno R., Kilpatrick D.G., and Resnick H.S. (1999): Posttraumatic

2. Stress Disorder in Adults Relative to Criminal Victimization: Prevalence, Risk Factors, and Comorbidity. In P.A. Saigh \& J.D. Bremner (Eds.), Posttraumatic Stress and Emotional Abuse of Teachers: A comprehensive text (pp. 44-68). Needham Heights, MA: Allyn \& Bacon.

3. Australian Education Union (AEU) (2003): Damage Control. [On Line; http:// www.aeufederal.org.au]

4. Benefield J. (2004): Teachers-The New Targets of Schoolyard Bullies? New Zealand: Post Primary Teachers Association, pp 1-23.

5. Boney-McCoy S., and Finkelhor D. (1995): Psychosocial Sequelae of Violent Victimization in A National Youth Sample. Journal of Consulting and Clinical Psychology; 63:726-736.

6. Connect Initiative (2002): Connect UK-001 project: Tackling Violence in Schools on a European- wide basis. Education and Culture. [On line; http://europa.eu.int/comm/education/connect/ selection.html

7. Day D.M., Golench C.A., MacDougall J., and Beals-Gonzaléz C.A. (1995): School Based Violence Prevention in Canada: Results of a national survey of policies and Programs. Ottawa, ON: Ministry of the Solicitor General of Canada.

8. DeVoe J., Peter K., Kufman P., and Ruddy S. (2002): Indicators of School Crime and Safety: 2002. U.S. Departments of Education and Justice. NCES 2003-009/NCJ 196753. Washington,
DC: 2002, p. 77. SOURCE: U.S. Department of Justice, Bureau of Justice Statistics, National Crime Victimization Survey, 1996 through 2000(1).

9. di MartinoV. (2002): Violence at the Workplace; the Global Response. African Newsletter on Occupational Health and Safety; Volume 12, number 1 .

10. Duhart D.T. (2001): Violence in the Workplace, 1993-99. National Crime Victimization Survey. Bureau of Justice Statistics. N Criminal J 190076; 1-12.

11. Fisher K ., and Kettl P. (2003): Teachers' Perceptions of School Violence. J Pediatr Health Care. Mar-Apr; 17(2):79-83.

12. Glasgow G. (2003): Media the Message. The Daily Camera. Retrieved .[ On line; April 26, from http://cfapps.bouldernews.com/printpage/ index.cfm].

13. Hamburg M.A. (1998): Youth Violence is A Public Health Concern. In D. S. Elliot, B.A. Hamburg, \& K. R. Williams (Eds.), Violence in American schools: A new perspective. New York: Cambridge University Press, pp. 31-54.

14. Johnson S.A., and Fisher K. (2003): School Violence: An Insider View. Am J Matern Child Nurs. Mar-Apr; 28(2):86-92.

15. Kimerling R., and Calhoun K.S. (1994): Somatic Symptoms, Social Support, and Treatment Seeking Among Sexual Assault Victims. Journal of Consulting and Clinical Psychology; 62: 333-340.

16. Kondrasuk J.N., Greene T., Waggoner J. et al. (2005): Violence affecting school employees. Education. Summer, pp 1-5. 
17. Levin P.F., Martinez M.Q., Walcott-McQuigg J., Chen S.P., Amman M., and Guenette C. (2006): Injuries Associated with Teacher Assaults: Magnitude, Nature, Cost, and Outcome. Am Asso Occup Health Nurs J. May; 549 (5):210-6.

18. Lyon D.R., and Douglas K.S. (1999): Violence against British Columbia Teachers. Report of the Simon Fraser University/British Columbia Teachers' Federation. Mental Health, Law, and Policy Institute. Simon Fraser University.

19. MacDonald I., daCosta J., and Maynes B. (1996): Reframing the Meaning of School Violence: Perceptions of Students. The Canadian Administrator; 36: 1-8.

20. Manitoba Teachers' Society (1990): Report of the Task Force on the Physical and Emotional Abuse of Teachers [on line].

21. Manitoba Teachers' Society (1993): Report on the Abuse of Teachers in Manitoba schools [On line].

22. Mushinski M. (1994): Violence in America's Public Schools. Stat Bull Metrop Insur Co. AprJun; 75(2):2-9.

23. National Center for Educational Statistics (NCES) (2003): Indicators of School Crime and Safety. [On-line Retrieved October 1, 2004. Available: http://nces.ed.gov/pubsearch/ pubsinfo.asp?pudid=2004004].

24. National Institute of Occupational Safety and Health (NIOSH) Grant No 1R010H00781601A1 (2004-2007) for Gerberich S (PI): Violence against Teachers: Etiology \& Consequences.
25. Needham A (2005): Workplace Bullying: The Costly Business Secret, Auckland: Penguin.

26. New Brunswick Teachers' Association. (1994). Towards Orderly Places of Learning: A report of the NBTA School Violence Survey. Fredericton, [On line].

27. Nolan P., Dallender J., Soares J., Thompsen S., and Arnetz B. (1999): Violence in Mental Health Care: The Experiences of Mental Health Nurses and Psychiatrists. J Adv Nurs; 30 (4):934-41.

28. Norris F.H. and Kaniasty K. (1994). Psychological Distress Following Criminal Victimization in the General Population: Cross-Sectional, Longitudinal, and Prospective Analyses. Journal of Consulting and Clinical Psychology; 62: 111-123.

29. Nova Scotia Teachers' Union. (1996): School Violence Increasing. Press Release. Halifax, [On line; http://nstu.ca].

30. Phillip B. (1999): Violence in South African Township Schools - an Exploration. Honours Research Dissertation. Institute of Criminology, UCT, Cape Town.

31. Post Primary Teachers Association (PPTA) (2004): School Anti-Violence Toolkit: A Resource to Assist Schools in Developing and Implementing Effective Anti-Violence Policies, Practice and Procedures, Wellington: NZ Post Primary Teachers Association.

32. Reiss, David John E., Richters Radke-Yarrow M., and Scharff D. (1993): Children and Violence. New York: The Guilford Press.

33. Richman J.A., Rospenda K.M., Nawyn S.J. (1999): Sexual Harassment and Generalized 
Workplace Abuse Among University Employees: Prevalence and Mental Health Correlates. Am J public Health. March 1999; 89:358-363.

34. Ruff J.M., Gerding G., and Hong O. (2004): Workplace Violence Against K-12 Teachers: Implementation Of Preventive Programs. AAOHN J. May; 52(5):204-9.

35. Saarela K.L. (2002): Violence at Work. African Newsletter on Occupational Health and Safety; 12(1).

36. Saskatchewan Teachers' Federation (1994): A Survey of the Abuse of Teachers: Report on the Results. Saskatoon, SK[On line].

37. Schonfeld -1(1995): Stress in One Occupational Group: Teachers. School of Education, City Col- lege of New York: NIOSHTIC-2 database schools, p. 67.

38. The Scottish Executive National Statistics Publication, Education Department, (2003): Incidents of Violence and Anti-Social Behaviour Against Local Authority School Staff in 2001/02.online.

39. Vossekuil B. (2002): The Final Report and Findings of the Safe School Initiative: Implications for the Prevention of School Attacks in the United States. Washington, D.C.

40. Weinhold B.K. (2003):"Bullying and School Violence: The Tip of the Iceberg".[On line; Retrieved April 27, 2003 from http:// www.balarad.net/clients/weinhold/ bullyingmain.html]. 